Hugoye: Journal of Syriac Studies, Vol. 13.1, 49-63

(C) 2010 by Beth Mardutho: The Syriac Institute and Gorgias Press

\title{
THE LUST OF THE BELLY IS THE BEGINNING OF ALL SIN \\ A PRACTICAL THEOLOGY \\ OF ASCETICISM IN THE DISCOURSES of PHILOXENOS OF MABBUG
}

\author{
ROBERT A. KITCHEN \\ KNOX-METROPOLITAN UNITED CHURCH \\ REGINA, SASKATCHEWAN
}

\begin{abstract}
The thirteen Discourses of Philoxenos of Mabbug are addressed to monks under his episcopal care and concern traditional challenges of the monastic and spiritual life. E. W. Budge suggested that Philoxenos was attempting to follow Aphrahat's choice of subjects and at first this seems to be the case. Later on, a progression based on Evagrius Ponticus' schema appears probable, beginning with the tenth memrä, "On the Lust of the Belly." The intention here is to demonstrate that this tenth memra is the critical Discourse in the collection, as Philoxenos shifts from the theology of the spiritual life and renunciation to the most significant practical aspect of monastic community life-the discipline of eating and the consequences of the undisciplined life, i.e., gluttony and fornication. This also indicates a shift in the distinction between the Upright and Perfect ones described in the Book of Steps and The Discourses from celibacy to conquering gluttony.
\end{abstract}


This paper is not finally about Philoxenos, but about the nature of Perfection in early Syriac asceticism. Perfection is not merely a theological construct or vision in the Syriac tradition, but a dynamic attempt to progress towards complete sanctification, often in the company of a community. The functioning of one of those attempts through a two-level hierarchy of the Upright (kène) and Perfect (gemire) in two major texts-the Book of Steps (Liber Graduum) and the Discourses of Philoxenos of Mabbug-is still enigmatic to those who try to comprehend the essential character of early Syriac asceticism.

It is not surprising to students of asceticism that the late-fourth century Book of Steps requires celibacy of one who wishes to ascend from Uprightness to Perfection. However, in the late-fifth/earlysixth century, the situation has changed and the monks to whom Philoxenos writes are all celibate. The intent of this paper is to suggest that for Philoxenos the taming of the passion of gluttonythe lust of the belly - has superseded celibacy as the entrance point from Uprightness into the realms of Perfection, a shift born out of practical ascetical experience.

To live in a quiet age was not the luxury of Philoxenos of Mabbug. Persecution and controversy assailed him throughout his entire life, for the years following the Council of Chalcedon in 451 were generally troubled times for the Syriac Church, and Philoxenos, it seems, consistently found himself in the eye of the storm.

By the late-fifth century monasticism had established itself as a powerful religious and political force. ${ }^{1}$ For Philoxenos, bishop of Mabbug in west Syria northeast of Antioch, the monks under his episcopal jurisdiction were his favorites, and correspondence with individual monks and communities comprised the majority of his literary output. The largest and most famous monastery at Senun, near Mabbug, was the recipient of his last letter which urged the monks there to stand firm by their miaphysite faith. ${ }^{2}$ It was to these monks at Senun, André de Halleux speculates, that Philoxenos

${ }^{1}$ Cf. David Brakke, Athanasius and the Politics of Asceticism (Oxford, 1995).

2 Philoxène de Mabbog, Lettres aux moines de Senoun, ed. André de Halleux, CSCO 231-232/Syr 98-99 (Louvain, 1963). 
directed his Discourses, ${ }^{3}$ which De Halleux believes was "probably the most read and recopied work"4 of Philoxenos-a collection of 13 mèmrè or Discourses on the ascetical life. ${ }^{5}$

I have been reading and pondering these Discourses for over three decades and am preparing a new translation and introduction for Cistercian Publications. Whimsically, I have called the Discourses the companion volume to the Book of Steps, yet for this chapter in Syriac asceticism these two works travel along a similar trajectory.

\section{ORgaNIZATION OF THE Discourses}

The starting point for all modern studies of the Discourses is E.W. Budge's two-volume edition of the Syriac text with an English translation and introduction. The only other modern language translation, Eugène Lemoine's French version, ${ }^{6}$ uses Budge's Syriac text as its base. In 2007, Sources Chrétiennes reissued SC 44 bis, a significant 'revue' by René Lavenant.7

Lemoine believes that the Discourses were written to be read in the monastery and were edited specifically for this purpose. ${ }^{8} \mathrm{He}$ sees no traces of miaphysitism in the Discourses. ${ }^{9}$ Irenée Hausherr had earlier promoted this view that the Christological ideas of the miaphysites have no influence on their ascetical and mystical teachings. ${ }^{10}$ Nevertheless, there are a number of "casual" remarks that reflect Philoxenos' Christological understanding sprinkled throughout the mèmre which are neither calculated nor programmatic for the content of the Discourses.

3 André de Halleux, Philoxène de Mabbog. Sa vie, ses écrits, sa théologie (Louvain: Imprimerie Orientaliste, 1963), 45.

${ }^{4}$ De Halleux, Philoxène de Mabbog. Sa vie, 283.

${ }^{5}$ Discourses of Philoxenus, Bishop of Mabbôgh, 2 vols., ed. E.A.W. Budge (London, 1894).

6 Philoxène de Mabboug, Homélies, tr. E. Lemoine, SC 44 (Paris, 1956).

${ }^{7}$ Philoxène de Mabboug, Homélies, tr. E. Lemoine; Nouvelle édition revue par R. Lavenant, S.J., SC 44 bis (Paris, 2007). My review of this new edition is included in this number of Hugoye.

${ }^{8}$ Lemoine, Homélies, 12-3.

${ }^{9}$ Ibid., 15.

${ }^{10}$ I. Hausherr, "Contemplation et Sainteté: Une remarquable mise au point par Philoxène de Mabboug” (RAM, 14 [1933]), 15. 
Philoxenos begins with an introductory memrä, and then proceeds with six pairs of mèmrè, each pair treating a single topic. The pairs are: Faith $(2 \& 3)$; Simplicity ( $\& \& 5)$, Fear of God (6 \& 7); Renunciation of the World (8 \& 9); Gluttony (10 \& 11); and Fornication (12 \& 13).

While maintaining that the Discourses are a unified work, Budge notes that "they (the manuscripts) were frequently divided into two volumes; the first volume contained the first nine, and the second volume the last four of the Discourses." 11 Budge speculates that Philoxenos probably intended the Discourses to be a supplement or sequel to the 22 Demonstrations of Aphrahat. ${ }^{12}$ To underline the literary connection, Budge includes a translation of Aphrahat's first Demonstration, also entitled "On Faith," in the edition of the Discourses.

Lemoine also attempts to discern a pattern in Philoxenos' organization of the Discourses and so developed a theory that stimulated a great deal of debate. ${ }^{13} \mathrm{He}$ observes that in each pair of memre written on the same topic the ideas of the first were relatively simple, while the ideas of the second were more sophisticated. Lemoine concludes that Philoxenos combined in his Discourses two series of mèmre written at different times for different purposes. Initially, Philoxenos dealt with each topic in one mèmrä, but after a certain interval of time he reworked his ideas into a theologically more mature second homily. During this "interval" Lemoine perceives Philoxenos' thought becoming more mystical. Lemoine theorizes that usually the first member of each pair was written in a moralistic tone "with the memory of what is said in the Holy Books"; the second member was written in a mystical tone "with the experience of what is said in the Holy Books." ${ }^{14}$

The further Lemoine tries to demonstrate his theory the more it begins to unravel. Upon closer analysis, Lemoine places two memré, the fourth on Simplicity and the sixth on the Fear of God, out of their expected sequence. Although these two mémrè are the first ones to deal with their respective topics, Lemoine assigns them to the second mystical series because they emphasize mystical

\footnotetext{
${ }^{11}$ Budge, Vol. II, lxxiii.

12 Ibid., II, lxxiii-lxxiv.

${ }^{13}$ Lemoine, Homélies, 20-4.

14 Ibid., 163.
} 
ideas and experience. Moreover, Lemoine writes, Philoxenos himself indicated the original order of the memre in the fifth Discourse: "We spoke in our preceding discourse [On Faith] of simplicity and innocence; it is of that useful subject that I wish to speak again now" (120:13-16). The fifth Discourse, therefore, should have been in the fourth position. ${ }^{15}$

Following this analysis, Lemoine's division of the Discourses is as follows: moralistic discourses-2, 5, 7, 8, 10, 12; mystical discourses-3, 4, 6, 9, 11, 13. The major problem with Lemoine's theory is that his classification of moralistic and mystical is too subjective, for depending upon one's definition of these concepts, one could contest either way the classification of any of the Discourses.

Scholars have felt compelled to develop theories about Philoxenos' organization and plan, and most see the influence of Evagrius Ponticus factored in. ${ }^{16}$ De Halleux suggests that the traditional collection of 13 mémré is probably an incomplete or unfinished work. In the introductory mémrā De Halleux sees Philoxenos proposing a three-part outline: mèmré $2-7$ deal with the beginning of the spiritual life or the "degree of the body"; memre 8-13 show the progress of the individual in the struggle against the passions or the "degree of the soul"; while the third part was to examine the "degree of the spirit." A series of $9^{\text {th }}-11^{\text {th }}$ century manuscripts reproduce ascetical florilegia which include extracts of mémrè 9 and 13 along with fragments on humility, penitence, and prayer. ${ }^{17}$ These fragments, De Halleux suggests, are from the last mèmre of the third part, the "degree of the spirit." 18

${ }^{15}$ Lemoine, Homélies, 163, 90-1.

${ }^{16}$ Cf. Paul Harb, 'L'attitude de Philoxène de Mabboug à l'égard de la spiritualité 'savante' d'Évagre le Pontique," in Mémorial Mgr. Gabriel KhouriSarkis (1898-1968), ed. F. Graffin (Louvain, 1969), 135-6. Also, John W. Watt, "Philoxenus and the Old Syriac Version of Evagrius' Centuries" (OC, 64 [1980]), 65-81.

17 François Graffin, S.J., "Le florilège patristique de Philoxène de Mabboug," in Symposium Syriacum 1972, Orientalia Christiana Analecta 197 (Rome, 1974), 267-90.

${ }^{18}$ De Halleux, Philoxène, 285-6. 
Evagrius' most enduring contribution has been his identifications of the eight vices or "principal thoughts." 19 The first two are gluttony or the lust of the belly and the lust of fornication - the second and third pairs following the renunciation of the world in Philoxenos' so-called second section. It seems likely that Philoxenos intended to complete the series of "principal thoughts": love of money, sadness, anger, listlessness, vainglory, and pride. Then he would move on to treat the topics of "the degree of the spirit" of which we may have been afforded a glimpse in the ascetical florilegia.

\section{MÉMRĒ ON THE LUST OF THE BELLY}

There is a vast amount of material in Philoxenos' Discourses, and even selecting one theme is too much for this article, but I believe the crucial memre are the $10^{\text {th }}$ and $11^{\text {th }}$ on gluttony or the lust of the belly. ${ }^{20}$ It is crucial, not for any academic schematization of the Discourses, but in order to perceive the spiritual dynamic that Philoxenos sees always at play in the infancy of the ascetical and monastic life. ${ }^{21} \mathrm{Up}$ to this juncture, Philoxenos has been talking about essentially spiritual matters and behavior-faith, simplicity, fear of God, even renunciation of the world-recognizing that the physical struggle of renouncing and departing from the world is in the past for his listeners. Now he turns to a literally visceral aspect of living in the solitude of the monastery, the craving for food that

19 Jeremy Driscoll, OSB, The 'Ad Monachos' of Evagrius Ponticus: Its Structure and a Select Commentary, Studia Anselmiana 104 (Rome, 1991), 12 17; also, Augustine M. Casiday, Evagrius Ponticus, Early Church Fathers (New York: Routledge, 2006).

20 Budge, Discourses (Vol. 1: Syriac text)—Discourse 10 "Against Gluttony,” pp. 353-419; Discourse 11 “On Abstinence,” 420-93.

${ }^{21}$ Philoxenos is not alone in attributing initial importance to gluttony and fornication. Not only does Evagrius provide a probable source, John Cassian locates the twin passions at the beginning of his Institutes, transl. Boniface Ramsey, Ancient Christian Writers 58 (New York: Paulist Press, 2000), Books Five and Six; and John Climacus also positions gluttony and fornication at the foot of the ladder in his The Ladder of Divine Ascent, transl. Colm Luibheid \& Norman Russell, The Classics of Western Spirituality (New York: Paulist Press, 1982): "Indeed I wonder if anyone breaks free of this mistress [the stomach] before he dies," p. 165. 
can set one's discipline askew. It is a daunting physical discipline, and therefore a path either to spiritual triumph or to spiritual destruction. This is the memra towards which all previous Discourses have been heading and without which these same memré cannot be fully comprehended.

\section{EXCERPT}

The question of whether Philoxenos wrote the Discourses to be read before the monks, or orally delivered them himself is not finally solvable. There are evidences of written style, as well as the vibrant cadence of the spoken word. Given that these mémre are 66 and 73 pages, respectively, in Budge's Syriac edition, if he preached them with a tremendous amount of energy and dynamic non-stop delivery, he might have been able to stop preaching around the 2 hour 10 minute mark for either mèmrä. My Puritan forerunners preached for two hours regularly in colonial New England, so it is possible, at least for the preacher!

From the first section of the $10^{\text {th }}$ memrä, here is an overture on gluttony that leaves little to conjecture regarding the place of gluttony in Philoxenos' monastic scheme.

This passion of the lust of the belly is the most despicable of all the passions. Once someone has become its servant and carried its heavy yoke upon his shoulder, it no longer gives him rest from its service, but works in him night and day, sending him like a wearied servant everywhere it wishes, not on beautiful paths, but on roads full of stumbling blocks and wherever harmful things are found. The friend of pleasures does not have eyes that see the light, because even if [he does have eyes,] they are darkened by the weight of food. Day is night to him, and night is a second death sinking his intelligence into the heaviness of sleep. His thoughts are scattered by ravings [as a result] of the body's dampness. The natural fire in him is cold because it is extinguished by the unusual dampness. His thoughts are obscured from knowledge because his soul's eye that seeks knowledge is shut. A heavy weight is suspended on him at all times, because joined to his body is another body of food. (Memrā 10; Vol. I, 353:9-355:6) 


\section{AgAinst THE LUST OF THE BELLY AND FORNICATION}

Philoxenos is far from finished with his diatribe. The fifth pair of memre deals with the lust of the belly (rabmat/regat karsa) or gluttony, and then abstinence or asceticism ('anwiyntä). Philoxenos states vividly how gluttony functions. "Therefore, the lust of the belly is the most disgraceful and abominable of all the lusts, and there is nothing similar to it among the rest of the other passions, except only in this: it is the mother and nurturer of them all. Just as a root bears the branches of the tree with everything in them, so also gluttony (ya'nuta $\vec{a}$ ) of the belly is the root of all the vices" (363:10-16). "Just as abstinence, that is, a fast from all foods, is the beginning of the way of the struggles of righteousness, so also the lust of the belly is the beginning of shameful works" (363:21364:2).

The rhetorical tenor of the $10^{\text {th }}$ mèmrà suggests an oral delivery, for the majority of the memra is a long diatribe against a hypothetical glutton $\left(y a^{\prime} n \vec{a}\right)$. His audience either was underwhelmed by the tedium or deeply engaged, participating gleefully in Philoxenos' caricatures of the self-absorbed glutton. "Therefore, the glutton is not capable of any other thing, except only this [business] of eating. For all actions, aside from this one, are considered empty by him. He does not think that a person was made for any other thing, except only for this thing, to fulfill his desires" (367:12-16).

Philoxenos sees at play a fundamental violation of the divinely created order. "This is justly worthy of punishment, not only on account of the fact that he is indulging his pleasures, and enrages God by his desire, but also because by his gluttony he damages healthy members that were well established by the Maker. Whoever corrupts the members of his body by means of his gluttony is an associate of a murderer and a companion of a destructive thief.... He damages the beautiful creation of God, and tears down the building of his body that the will of the architect had previously built" (380:12-7, 22-3). And there is a fundamental Edenic transgression committed by the glutton as well. "You have been made a god by the True God, but have you made your belly God? .... Your Lord has loved you to the point that he would become food for you, but you, for his love, [why] do you not abstain from vile foods? The Living One is dead and has been buried in order to 
save you, yet have you made yourself a tomb for food?" (382:1718, 24-383:2)

Philoxenos does lighten the lesson humorously. "Perhaps the feet of Abraham when love was carrying them and running to the herd in order to bring a calf to the angels were not as light as the feet of the glutton [who] rushes to whomever brings him food" (387:15-20). "Two eggs are more dear to him than the New and Old [Testaments]" (389:8-9).

Philoxenos finds numerous gluttonous occasions in the Biblical narrative to illustrate his cautionary tale. Adam fell from innocence through the lust of the belly (Genesis 3:6) (412:4-414:5). Esau lost his birthright and blessings while merely eating lentils (Genesis 25:29-34) due to his lust for food (414:18-20). Elijah, on the other hand, ate meat (1 Kings 17:6), but was considered spiritual (452:2-17). Then the people of Israel forgot God on account of their food and worshipped instead the golden calf (Exodus 32:1-6) (414:20-2). Even the drinking of cold water, if done with lust, can bring one down, as nearly happened to David at Bethlehem before he poured out the water before the Lord to suppress his lust (2 Samuel 23:15-7) (452:18-453:8).

Positively, Philoxenos tells of Daniel and the three young men (Daniel 1:3-16) who refused to eat the rich diet of King Nebuchadnezzar's court for three years and wound up being in better physical condition than those who did eat all the rich foodand the young men also received revelations of divine knowledge as a spiritual dividend for their discipline (471:1-473:12).

Philoxenos understands the story of Gideon's selection of his attack force against the Midianites (Judges 7:1-23) as a test in the struggle against the lust and passion of fornication. ${ }^{22}$ Because the

${ }^{22}$ Since E.W. Budge believed that there was a conscious attempt on Philoxenos' part to continue or imitate Aphrahat's Demonstrations, it is appropriate to note that Aphrahat's exegesis of the Gideon story is likewise detailed, though with a different interpretation (Demonstration 7; col. 341:15-345:26). George Nedungatt sees the retelling of the Gideon story (Judges 7) to be the narrative of the admission of candidates to the bnay qyama or Covenanters. Celibacy is the dividing line again, but the Midianites are barely mentioned, and the harshness of fornication is not raised. Cf. G. Nedungatt, "The Covenanters of the Early Syriac-Speaking Church," OCP 39 (1973), 191-215, 419-44, esp. 438-42. 
Israelites had whored with the daughters of Midian (Numbers 25:1), the army of Midian now symbolizes fornication. Philoxenos' physiology of fornication assumes that lust is fed by too much water, so taking in only a little water with caution-as did those 300 - dries up the passion. The sound of the horn is the commandment of God; the breaking of the pitchers is the breaking of the passion of fornication; and the light inside the pitcher is that of divine knowledge (597:15-601:18). Philoxenos interprets this act of lapping up water as a rejection of fornication - an embracement of celibacy - and therefore a monastic requirement.

The desire for food, not food or eating itself, is the stumblingblock for the Upright. "Do not think that food is naturally blameworthy ('adila $)$, but [only] when one eats it with desire" (446:7-9). To direct one's struggle against food is futile and misguided. "Therefore, do not fight against food, but against desire. Therefore, if you fight against one [kind of] food, when you have been victorious in battle over one, another will fight against you; but if you are victorious over desire in one thing [you are victorious over] many things" (441:18-22). To prove his point that desire is the real impediment, Philoxenos employs the quintessential Biblical meal. "It was not the fruit that Eve had eaten [that] had engendered death, but the desire of the fruit [that] had brought forth death" (446:11-3). ${ }^{23}$

Philoxenos, addressing his recently-arrived monks, presents an orderly system of asceticism and spirituality aimed towards Perfection-which approximates the state of apatheia or passionlessness (la $\underline{b} \bar{a} \bar{s} \bar{u} \bar{s} \bar{u} t \bar{a})$. The Discourses were a sort of "remedial" course in the foundations of spirituality for the novice monks, many of whom were still insecure in their vocation and vulnerable to temptations brought with them from "the world" in their heads.

\section{WHY GLUTTONY?}

The lust of the belly or gluttony may seem an odd focus for a practical theology of asceticism. The key is in the development of

23 Scripture does not give us much detail, Philoxenos says, but oral tradition indicates that the fruit Eve ate was from the fig tree (têta) (rdursd) (446:17-23). 
the status of Perfection seen played out between the fourth-century Book of Steps and the Discourses of Philoxenos, the only two Syriac works to describe the dichotomy of the Upright (kène) and the Perfect (gmire) within a faith community.

The Book of Steps or Liber Graduum, is a mid-to-late-fourth century collection of 30 mèmré, written by an intentionally anonymous author inside the Persian Empire (northeast Iraq). ${ }^{24}$ The mémrè treat a wide range of ascetical and theological subjects in a variety of literary genres, but what most readers immediately pick up on is the pervasive organization of this pre-monastic community into the two levels of the Upright and Perfect. ${ }^{25}$

Briefly, the Upright ones are lay people, married, work at a job, earn money and have possessions, but have accepted the commission to perform the active acts of charity within the town or village in which they live: feed the hungry, clothe the naked, heal the sick, and also provide for the physical needs of the Perfect ones (occasionally a point of tension). The Perfect, on the other hand, are celibate, pointedly do not work or perform labor, have no possessions or home and thereby wander, teach, and mediate conflicts, and practice unceasing prayer.

What is of concern in examining Philoxenos' use of the same terminology and institutions are the boundary lines and entry points. For the Book of Steps, the critical boundary is the requirement of celibacy and renunciation of the world. Since this is not yet a monastic community isolated from the town, the Perfect have to renounce the world "out in the open," so to speak, while still remaining in public view. The Upright, committed as they are to the Gospel principles, are reluctant to become celibate and renounce their marriages. It appears that the decision to become Perfect or Upright is made at a very early stage in one's spiritual

${ }^{24}$ Liber Graduum, ed. M. Kmosko, Patrologia Syriaca 3 (Paris, 1926) Syriac text and Latin translation, plus introduction and other Greek texts associated with the Messalian controversy. The Book of Steps: The Syriac Liber Graduum, English translation \& introduction by R.A. Kitchen \& Martien F.G. Parmentier, Cistercian Studies 196 (Kalamazoo, Michigan: Cistercian Publications, 2004).

${ }^{25}$ A fuller description of these two levels is found in the Introduction to the above translation, xxxviii-xlvii. 
journey and practically difficult to alter at a later juncture. Not very many are willing, living in the world, to make that kind of decision.

A century and a half later, Philoxenos' utilization of the same structure and terminology occurs within a much changed ecclesiastical and social situation. ${ }^{26}$ The Upright and Perfect ones are described in very similar terms to the Book of Steps, though Philoxenos never directly cites the earlier work. No longer, however, is the setting in the unknown town where the Book of Steps was lived out, but in a monastery, Senun perhaps, where the Christian life takes on a quite different shape and economy. All the residents have departed from "the world"-albeit for a variety of spiritual and often questionable reasons-leaving behind possessions and family, and for the time being are celibate. That weighty and momentous choice one has to make has already been made.

Philoxenos emends the Upright/Perfect dichotomy into a continuum applicable to his audience. A young monk, still not sure of what he has bargained for, begins in the status of Uprightness and progresses spiritually towards the status of Perfection. The level which one has attained is a matter of spiritual direction and discernment rather than overt physical actions and accomplishments.

Philoxenos begins his instruction on the ascetical life with the Evagrian fundamentals of the ascetic life-faith, simplicity, and the fear of God. Interpreted in the context of monastic life, these can be received as solid catechetical instruction for a novice in the Christian faith, as probably some of his monks were. He becomes more serious when he reaches "the renunciation of the world." The shift from the physical to the spiritual realm is apparent, for Philoxenos does not need to urge anyone to "depart from the world." However, many have not spiritually renounced the world, still dwelling mentally in the memories of worldly settings of family and marriage, instead of their minds dwelling spiritually in the kingdom of heaven or the Garden of Eden.

All of this theological musing on renunciation is still prolegomena for the monks since it concerns an action and event on which they have already embarked, however imperfectly and incompletely. In Mèmrä 10, Philoxenos drops the shoe and talks

${ }^{26}$ Ibid., lxxxiii. 
bluntly of the beginning of all sin. Gluttony or the lust of the belly is a psychosomatic stumbling block, not only to physical health, but also to spiritual vitality and divine knowledge. In the physiology of asceticism the lust of the belly leads directly to the spirit of fornication, and then to worse spiritual malaise. This is not manichaeistic dualism at play, for nothing is wrong with food, Philoxenos emphasizes, it is a matter of how you eat, of not allowing desire to have control over you. In Philoxenos' favorite Scriptural example of Daniel and the three young men groomed for greatness at the Persian court, it is the right kind of food that matters most—not rich foods, but simple fare (471:1-473:12).

In the two long memrè on gluttony, fasting (sawma $)$ is not the primary focus, since the most difficult of sins develop in situations where the individual does not recognize the dire consequences and sinfulness of what he is doing. Philoxenos cautions, rather warns, against the delusion that if the monk believes he has conquered the rich and fancier foods that he has defeated gluttony. No, one must be alert even more to the temptations of eating too much plain, regular food. Once one is in control regarding plain food, then the challenge of richer foods is a moot point. ${ }^{27}$

A later important figure in Greek monastic spirituality and disciple of Evagrius, John Climacus, similarly places his greatest worries around the times when his charges are not formally fasting. The days to fear for the monk are, in fact, the 'feast days. 28 Philoxenos does not address this circumstance directly, but his concern is also for the situations in which the monk's weaknesses indulge the lust of the belly under legitimate cover.

Of course, Philoxenos' intention is to tame, transcend, and be victorious over the lust of the belly and that has become the new boundary line for his understanding of the ascetical and monastic life, superseding the requirement of celibacy for entry into Perfection for the Book of Steps. A decision which leads to an authentic commitment typically is of sufficient stringency that one cannot make it with half-measures. Gluttony is the beginning of all

${ }^{27}$ Mèmrā 10, 415:11-416:8.

28 "The gluttonous monk celebrates on Saturdays and Sundays. He counts the days to Easter, and for days in advance he gets the food ready. The slave of the belly ponders the menu with which to celebrate the feast." John Climacus: The Ladder of Divine Ascent, 165. 
sin, and the rejection of its control over one's body and soul necessitates at first a clearly uncomfortable transformation of one's entire being, spirit, soul, and body. The "battle" (taktū̌săa qräbä) has moved inwardly, where gluttony plays out its beguiling challenge.

This emphasis upon gluttony and then fornication does seem to take us back to the perception that Philoxenos was attempting an Evagrian model of sins and vices in the construction of his memré. ${ }^{29}$ However, given that there is no clear manuscript evidence for a continuation of the Discourses, I suggest that this is all Philoxenos intended to write and deliver. The practical skills of prayer and fasting and worship can be left to other hands, for if you have extinguished the all-consuming lust of the belly, Philoxenos keeps saying, everything else is a piece of cake.

\section{BIBLIOGRAPHY}

Discourses of Philoxenus, Bishop of Mabboghh, 2 vols., ed. \& tr. E.A.W. Budge (London, 1894).

Philoxène de Mabboug. Homélies, tr. E. Lemoine. Sources Chrétiennes 44 (Paris, 1956).

Philoxène de Mabboug. Homélies, tr. E. Lemoine; Nouvelle édition revue par R. Lavenant, S.J. Sources Chrétiennes 44bis (Paris, 2007).

Philoxène de Mabbog. Lettres aux moines de Senoun, ed. André de Halleux. CSCO 231-232/Syr 98-99 (Louvain, 1963).

André de Halleux, Pbiloxène de Mabbog: Sa vie, ses écrits, sa théologie (Louvain: Imprimerie Orientaliste, 1963).

Liber Graduum, ed. Michel Kmosko. Patrologia Syriaca 3 (Paris, 1926).

The Book of Steps: The Syriac Liber Graduum, English translation \& introduction by Robert A. Kitchen \& Martien F.G. Parmentier. Cistercian Studies 196 (Kalamazoo, Michigan: Cistercian Publications, 2004).

Aphraatis Sapientis Persae Demonstrationes, ed. \& tr. J. Parisot. Patrologia Syriaca 1-2 (Paris, 1894, 1907).

John Cassian. The Institutes, tr. Boniface Ramsey. Ancient Christian Writers 58 (New York: Paulist Press, 2000).

${ }^{29}$ Cf. David A. Michelson, Practice Leads to Theory: Orthodoxy and the Spiritual Struggle in the World of Pbiloxenos of Mabbug (470-523), Ph.D dissertation (Princeton University, 2007). Chapter 2: Monastic Practice and Divine Knowledge: The Evagrian Background to Philoxenos' Vision of Christian Faith and Life. 
John Climacus. The Ladder of Divine Ascent, tr. Colm Luibheid \& Norman Russell. The Classics of Western Spirituality (New York: Paulist Press, 1982).

David Brakke, Athanasius and the Politics of Asceticism (Oxford, 1995).

Augustine M. Casiday, Evagrius Ponticus. Early Church Fathers (New York: Routledge, 2006).

Jeremy Driscoll, OSB, The 'Ad Monachos' of Evagrius Ponticus: Its Structure and a Select Commentary. Studia Anselmiana 104 (Rome, 1991), 12-17.

François Graffin, S.I., "Le florilège patristique de Philoxène de Mabboug." In Symposium Syriacum 1972. Orientalia Christiana Analecta 197 (Rome: 1974), 267-290.

Irenée Hausherr, "Contemplation et Sainteté: Une remarquable mise au point par Philoxène de Mabboug." Revue d'Ascétique et de Mystique 14 (1933): 15.

Paul Harb, "L'attitude de Philoxène de Mabboug à l'égard de la spiritualité 'savante' d'Évagre le Pontique.” In Mémorial Mgr. Gabriel KhouriSarkis (1898-1968), ed. F. Graffin (Louvain, 1969), 135-6.

David A. Michelson, Practice Leads to Theory: Orthodoxy and the Spiritual Struggle in the World of Philoxenos of Mabbug (470-523), Ph.D dissertation (Princeton University, 2007).

George Nedungatt, "The Covenanters of the Early Syriac-Speaking Church." Orientalia Christiana Periodica 39 (1973): 191-215, 419444.

John W. Watt, "Philoxenus and the Old Syriac Version of Evagrius' Centuries." Oriens Christianus 64 (1980): 65-81. 
